\title{
Musschia isambertoi M. Seq., R. Jardim, M. Silva \& L. Carvalho (Campanulaceae), a new species from the Madeira Archipelago (Portugal)
}

\author{
by \\ Miguel Menezes de Sequeira ${ }^{1}$, Roberto Jardim², Magda Silva ${ }^{1} \&$ Lígia Carvalho $^{1}$ \\ ${ }^{1}$ Dep. Biologia/CEM, Universidade da Madeira, Campus da Penteada, 9000-390 Funchal, Portugal \\ ${ }^{2}$ Jardim Botânico da Madeira, Caminho do Meio, 9064-512 Funchal, Portugal \\ sequeira@uma.pt, robertojardim.sra@gov-madeira.pt
}

\begin{abstract}
Menezes de Sequeira, M., Jardim, R., Silva, M. \& Carvalho, L. 2007. Musschia isambertoi M. Seq., R. Jardim, M. Silva \& L. Carvalho (Campanulaceae), a new species from the Madeira Archipelago (Portugal). Anales Jard. Bot. Madrid 64(2): 135-146.

A new species of Musschia Dumort. (Campanulaceae), endemic from Madeira Archipelago (Portugal), is described as Musschia isambertoi M. Seq., R. Jardim, M. Silva \& L. Carvalho. Both vegetative and reproductive structures have been studied and are remarkably distinct from the recognized species $[M$. aurea (L. f.) Dumort. and M. wollastonii Lowe]. A full description and a diagnosis are included as well as line art, color drawings and pictures. Diagnostic characters are discussed and compared with those of the closely related species. The new species has a very restricted distribution occurring in two isolated populations in the Deserta Grande Island (Madeira Archipelago, Portugal). Nomenclatural aspects on the genus Musschia Dumort. are discussed and a diagnostic key for the species is also included.
\end{abstract}

Keywords: Musschia aurea, Musschia wollastonii, Deserta Grande, endemism, taxonomy.

\section{Introduction}

The Madeira archipelago is composed of three groups of islands, Porto Santo with about $20 \mathrm{My}$., Madeira and Desertas more recent and sharing a common geological origin. The Madeira island is situated between $32^{\circ} 38^{\prime}$ and $32^{\circ} 52^{\prime} \mathrm{N}$ and $16^{\circ} 39^{\prime}$ and $17^{\circ} 16^{\prime} \mathrm{W}$, at approximately $600 \mathrm{~km}$ northwest of the Western African coast. It is a within-plate volcanic island the tip of a stratovolcano about $6 \mathrm{~km}$ high. The emerged part of the island dates back to Post-Miocene times, $<5.6$ My. (Ribeiro \& al., 2005), and the more recent volcanic

\section{Resumen}

Menezes de Sequeira, M., Jardim, R., Silva, M. \& Carvalho, L. 2007. Musschia isambertoi M. Seq., R. Jardim, M. Silva \& L. Carvalho (Campanulaceae), una nueva especie del archipiélago de Madeira (Portugal). Anales Jard. Bot. Madrid 64(2): 135-146 (en inglés).

Se describe una nueva especie de Musschia Dumort. (Campanulaceae), endémica del archipiélago de Madeira (Portugal), Musschia isambertoi M. Seq., R. Jardim, M. Silva \& L. Carvalho. La morfología de las estructuras vegetativas y florales estudiadas es claramente distinta de la de las otras dos especies conocidas, Musschia aurea (L. f) Dumort. y Musschia wollastonii Lowe. Se incluyen: una descripción y una diagnosis, ilustradas por imágenes, una lámina en blanco y negro y una en color. Se comparan y discuten los caracteres diagnósticos dentro del conjunto de especies del género. La nueva especie es endémica de la isla Deserta Grande (archipiélago de Madeira, Portugal). Se discuten aspectos nomenclaturales y se incluye una clave de las especies conocidas para Madeira.

Palabras clave: Musschia aurea, Musschia wollastonii, Deserta Grande, endemismo, taxonomía.

activity took place 6000-7000 years B.P. (Geldmacher \& al., 2000). The Madeira island has $737 \mathrm{~km}^{2}$ of surface. The maximum altitude is at Pico Ruivo, reaching $1861 \mathrm{~m}$ above sea level.

To the southeast the Madeira archipelago is continued by the Desertas sub-archipelago composed by three small islands. The northernmost is Ilhéu Chão (ca. 0.5 $\mathrm{km}^{2}$ ), which is also the smallest with only $100 \mathrm{~m}$ above sea level. The largest, Deserta Grande $\left(\mathrm{ca} .10 \mathrm{~km}^{2}\right)$, has a maximum altitude of $442 \mathrm{~m}$ above sea level. Finally Bugio (ca. $3 \mathrm{~km}^{2}$ ), the southern island has a maximum altitude of $348 \mathrm{~m}$ above sea level (Press \& Short, 1994). 
The vascular flora of Madeira comprehends 1226 species (Press \& Short, 1994), including 780 autochthonous. Of these 234 are Macaronesia endemics (Vieira, 1992), 157 of them restricted to Madeira (if hybrids are to be considered the total number rises to 165, Jardim \& Francisco, 2000). Six endemic genera occur in the Madeira archipelago: Chamaemeles Lindl. (C. coriacea Lindl., Rosaceae), Melanoselinum Hoffm. [M. decipiens (Schrad. \& J.C. Wendl.) Hoffm., Apiaceae], Monizia Lowe (M. edulis Lowe, Apiaceae), Parafestuca E.B. Alexeev [P. albida (Lowe) E.B. Alexeev, recently ascribed to Koeleria as Koeleria loweana Quintanar, Catálan \& Castrov., Poaceae], Musschia Dumort. [until now M. aurea (L. f.) Dumort. and $M$. wollastonii Lowe, Campanulaceae] and Sinapidendron Lowe $[S$. angustifolium (D.C.) Lowe, S. frutescens (Aiton) Lowe, S. gymnocalyx (Lowe) Rustan, S. rupestre Lowe and S. sempervivifolium Menezes, Brassicaceae]. The 15 Macaronesian endemic genera include: Aichryson Webb \& Berthel. and Monanthes Haw. (Crassulaceae), Argyranthemum Webb, Pericallis Webb \& Berthel. and Schizogyne Cass. (Asteraceae), Bencomia Webb \& Berthel. and Marcetella Svent. (Rosaceae), Bystropogon L'Hér. and Cedronella Moench (Lamiaceae), Drusa DC. (Apiaceae), Isoplexis (Lindl.) Benth. (Scrophulariaceae), Phyllis L. (Rubiaceae), Picconia DC. (Oleaceae), Semele Kunth (Ruscaceae) and Visnea L. f. (Theaceae). According to Press \& Short (1994), the most important families and also the ones with the most endemic species are: Asteraceae (132 species, 24 endemics), Brassicaceae (47 species, 11 endemics), Crassulaceae (20 species, 7 endemics), Lamiaceae ( 39 species, 9 endemics), Liliaceae s.l. (24 species, 7 endemics) and Poaceae (139 species, 8 endemics). There are also 75 species of ferns including 14 Madeira and Macaronesian endemics.

The family Campanulaceae includes around 82 genera and 2000 species (Mabberley, 1997). In the Macaronesian region two genera and eight endemic species are recognized, Azorina Feer a monospecific genus [Azorina vidalii (H.C. Watson) Feer] endemic from the Azores archipelago, Musschia Dumort. endemic from the Madeira archipelago with two recognized species M. aurea (L. f.) Dumort. and M. wollastonii Lowe, the Canary islands endemics Canarina canariensis (L.) Vatke and Campanula occidentalis Y. Nymann, the Cape Vert endemics Campanula bravensis (Bolle) A. Chev. and Campanula jacobaea C. Sm. ex Hook. and Wablenbergia lobelioides (L. f.) Link subsp. lobelioides common to Madeira, Canary and Cape Vert archipelagos (Hansen \& Sunding, 1993; Tebbs, 1994; Turland, 1994; Acebes Ginovés \& al., 2004; Sánchez-Pinto \& al., 2005; Silva \& al., 2005).
The genus Musschia was first isolated from Campanula L. by Dumortier (1823) based on Campanula aurea L. f. The differential characters of Musschia were described by Dumortier (op. cit.) as "Car. Diff. Calyx quinquepartitus. Corolla basi calycis inserta, quinquepartita. Stamina basi serrato-dillatata inflexa. Stigmata quinque convoluta. Capsula quinquelocularis". The name Musschia was dedicated to Jean Henri Musshe (1765-1834), Director of the Gent Botanical Garden by Dumortier (1823).

As stated, the first species was described previously by Linnaeus f. (1782) as Campanula aurea L. f. as "Campanula (aurea) capsulis quinquelocularibus, stigmatibus, quinquefidis, caule paniculato, foliis duplicatoserratis; Habitat in Insula Madera. Fr. Masson. Caulis paniculati, rupibus adpressi. Folia lanceolata, glabra. Calyx superus, coloratus. Corollae tubus a calyce distans: laciniis linearibus, reflexis".

Later Dumortier (1823) segregated the genus Musschia from Campanula based on Campanula aurea L. f., as M. aurea (L. f.) Dumort., and apart from the type specie, he described Musschia angustifolia Dumort. Later Lowe (1856) described M. wollastonii Lowe.

The early (1777-1830) references to Musschia (as Campanula L.) are all presumably based on seeds taken to the mainland from Madeira by Masson but also (possibly) by other authors. Ker Gawler (1815) not only includes a beautiful drawing of Musschia aurea (as Campanula aurea), but also a full and detailed description of this species. The seeds, as stated by Ker Gawler (op. cit.), were taken to England by Masson in 1777, previous to the description by Linnaeus $\mathrm{f}$. (1782). The list of plants collected in Madeira by Francis Masson, including notes, was never published. Two cultivated species at Kew Gardens are referred by Ker Gawler (op. cit.) but the second species corresponds to Campanula lobeliodes L. f. [later included in the genus Wablenbergia as W. lobelioides (L. f.) Link]. Musschia aurea had already been referred by Aiton (1789) as Campanula aurea L. f. cultivated in Kew Gardens. The early history of Madeira Campanulaceae, as with many other species and families, seems to have an origin in Masson's collections, lists and cultivations.

Ker Gawler (1815) refers to Campanula aurea with two varieties, $\alpha$ latifolia, which he refers to an icon in Ventenat (1805), and $\beta$ angustifolia, with no description other than a reference to Jacquin (1804) Plantarum Rariorum Horti Caesari Schoenbrunnensis Descriptiones et Icones. The line drawing in Jacquin (op. cit) comes with no description or table but clearly corresponds to a narrow leaved plant (Fig. 1). The publi- 


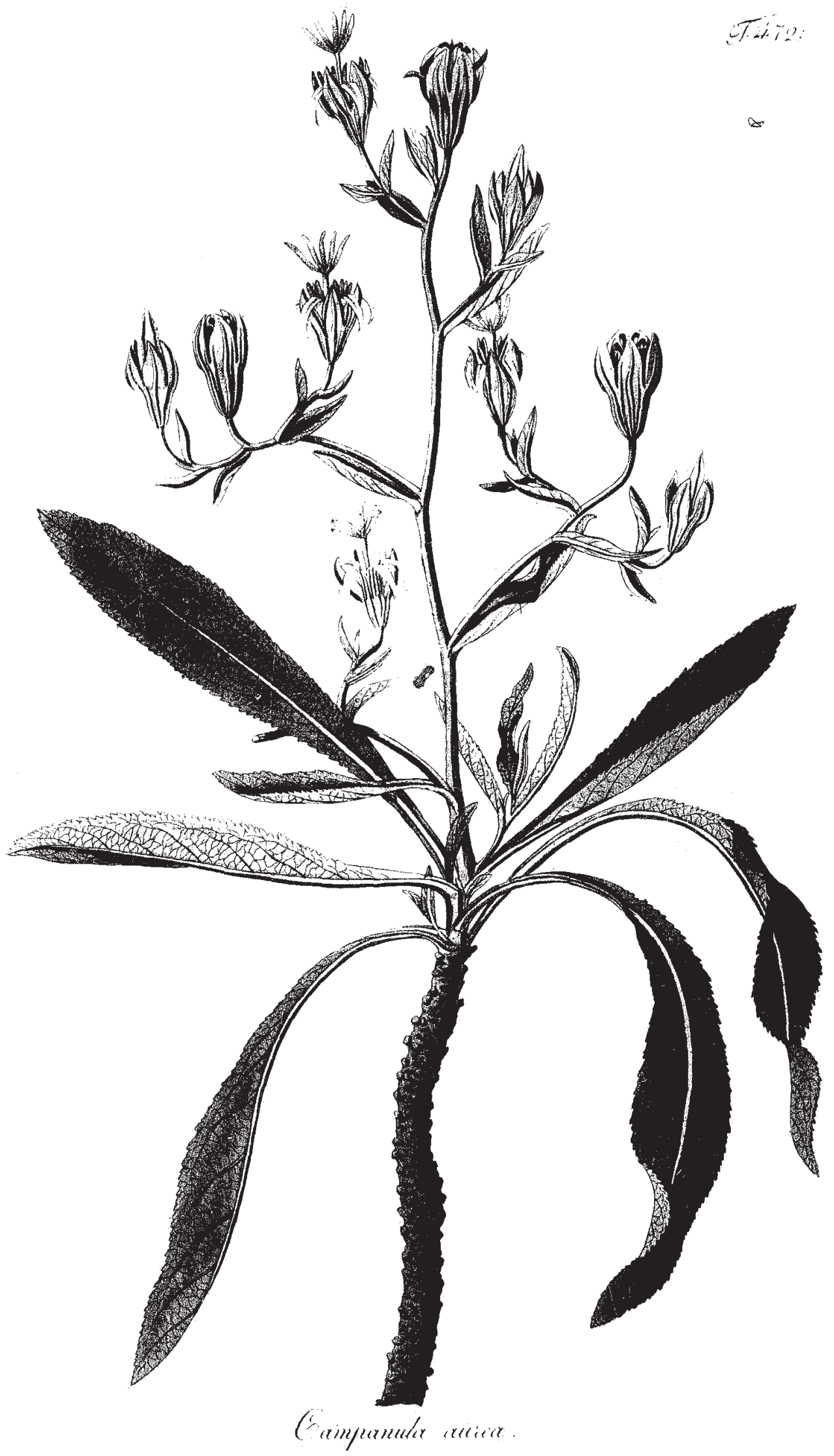

Fig. 1. Reproduction of the lamina of Campanula aurea L. f. included in Jacquin (1804) [from http://gallica.bnf.fr]. This plate was referred by Ker Gawler (1815) as Campanula aurea L. f. $\beta$ angustifolia. 
cation Jardin de Malmaison by Ventenat (op. cit.) includes drawings by Redouté.

Later, De Candolle $(1830,1838)$ refers to Musschia aurea and to the unpublished notes by Masson to cite the $\beta$ angustifolia (which he describes as foliis angustioribus). However, Dumortier (1823) had already proposed the name and given a description of these narrow leaved plants as Musschia angustifolia Dumort. This name is presumably based on Ker Gawler (1815, as C. aurea var. angustifolia) while Dumortier makes no reference to previous descriptions or icons of this narrow leaved variety, he does, however, distinguish the habitat of $\alpha$ (Musschia aurea) "in littore" and $\beta$ (Musschia angustifolia) "In interioribus insulae", suggesting that he based his notes on Ker Gawler (op. cit.) which states the same geographic pattern based on Masson's unpublished notes.

Dumortier (1823) is in fact the first to give a description and to name correctly the narrow leaved Musschia aurea plants. If no plants were to be found in order to name a lectotype, it would be advisable to elect the icon published by Jacquin (1804).

However, Musschia angustifolia Dumort. has not been recognized by later authors, in fact only two species, M. aurea and M. wollastonii, are included in the genus Musschia Dumort. by Lowe $(1856,1868)$, Menezes (1914) and the more recent authors (Hansen \& Sunding, 1993; Turland, 1994; Jardim \& Francisco, 2000; Costa \& al., 2004).

\section{Material and Methods}

Plants belonging to the new taxon were collected during spring of 2006 in the Desertas islands and deposited at MA (typus). Studied plants of the genus Musscbia were examined from MADJ (including MADS) and MADM. Macroscopic analysis was performed using a binocular microscope Zeiss model SV 11 APO.

The distribution map is based on geographic coordinates of the studied specimens converted to Cartesian coordinates using a local Datum (Porto Santo) and plotted using ArcView GIS 3.1.

\section{Results and Discussion}

During field work in 2006, M. Silva and L. Carvalho collected Musschia specimens in Deserta Grande at Fajã Pequena. These specimens present a distinctive morphology not within the variability of the previously described taxa (e.g. leaf size, shape and indumentum, the inflorescence architecture including branching and flower colours). Accordingly a new species is proposed.
Musschia isambertoi M. Seq., R. Jardim, M. Silva \& L. Carvalho, sp. nov. (Figs. 2, 3)

Speciebus Musschia aurea Dumort. et M. wollastonit Lowe similis; ab eis vero differens caule florifero nonnumquam $1.5 \mathrm{~m}$ alto atque tantum apice ramoso, floribus in apicibus axis principalis atque ramorum dense congesti, sepalis autem apice atque nervis castaneo-rubentibus, corollis viridibus (tantum basi flavescentibus), antheris maioribus (c. $15.5 \mathrm{~mm}$ ), lobis denique stigmatis pariter maioribus (c. $16 \mathrm{~mm}$ ).

Tall rosetted monocarpic plant (Fig. 3), up to $2 \mathrm{~m}$. Stem stout, ascending and short, up to $40 \mathrm{~cm}$, unbranched (Fig. 3). Leaves 25-33 × 11-13 cm, rigid, dull green with whitish veins, semi-clasping the stem, with indistinct petiole, oblanceolate, herbaceous, abaxial face glabrous except for the pubescent veins with hairs $0.3-0.4 \mathrm{~mm}$, adaxial face sparsely scabrid; margin shallowly undulated, bi-serrate (Figs. 2 b, 3). Inflorescence (Fig. 2 a, 3) up to $150 \mathrm{~cm}$ long, unbranched except for the terminal part, with 2-3(4) long (up to $25 \mathrm{~cm}$ ) branches disposed at a right angle to the main axis; bracts (Fig. 2 g) gradually shorter towards the top, $1.5-2 \mathrm{~cm}$ oblanceolate to lanceolate, undulate, clasping the stem and enrolled to their adaxial face (Fig. 2 e); the flowers densely crowded on the apex of the main axis and less so on the branches (Figs. 2 a, 3, 5). Flower (Figs. $2 \mathrm{f}, \mathrm{h}, 7$ a) up to $5 \mathrm{~cm}$, nectariferous; green, yellowish with reddish-brown tones, axillary to short bracts up to $2 \mathrm{~cm}$ oblanceolate to ovate, acuminated; with a usually short and puberulous pedicel. Calix (Figs. 2 e, 7 a) with sepals 23 $25 \times 5-7.4 \mathrm{~mm}(10 \mathrm{~mm}$ at the base), green with reddish brown apex and veins, sometimes yellowish towards the base, oblanceolate to oblong, sub-apiculate to acuminate, sepals with 3 nerves, the central larger, the margin and apex reticulate, puberulous with hairs up to 0.05-0.1 mm. Corolla bright green (Figs. $2 \mathrm{~h}, 7$ a), with tube $13-14.5 \mathrm{~mm}$, yellowish towards the base, lobes ca. $20 \times 4.5-5(6) \mathrm{mm}$, narrowly triangular-lanceolate, acuminate, erect before anthesis, arcuate deflex during anthesis. Stamens (Fig. 2 i) with filament 10-11 $\mathrm{mm}$, winged, 2.4-2.5 $\mathrm{mm}$ wide at the base; anthers $15.2-15.5 \mathrm{~mm}$, shortly apiculate, $0.5-0.8 \mathrm{~mm}$, subcordate. Pistil (Figs. 2 j, 7 a) with style $29-30 \mathrm{~mm}$, stigma $15-16.3 \times 2.5-3 \mathrm{~mm}$, scabrid towards the base with hairs 0.2-0.4 mm. Hypantial tube (Figs. 2 e, h, j, 7 a) 16-17 $\times 17 \mathrm{~mm}$, minutely scabrous with hairs $0.2(0.1$ $0.3) \mathrm{mm}$, green with a bright yellow apical ring and reddish-brown and green ribs. Capsule n.v. Plant pollinated by lizards (Lacerta dugesii mauli).

Type specimens. Portugal, Madeira: Ilhas Desertas, Deserta Grande, perto da Fajã Pequena, Porto das 


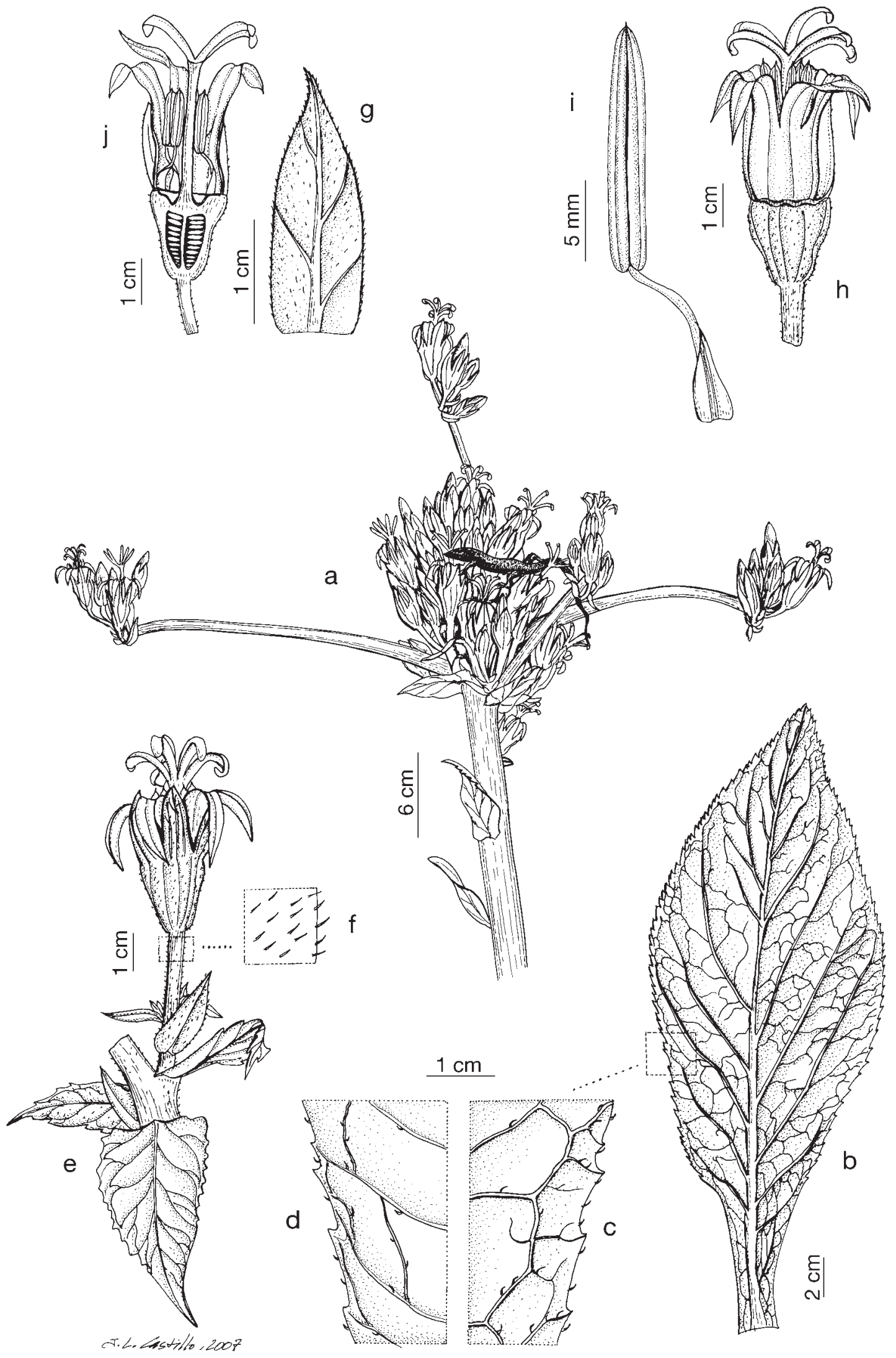

Fig. 2. Musschia isambertoi: $\mathbf{a}$, inflorescence; $\mathbf{b}$, leaf; $\mathbf{c}$, detail of the abaxial leaf surface; $\mathbf{d}$, detail of the adaxial leaf surface; e, portion of an inflorescence lateral branch; $\mathbf{f}$, indumentum of the pedicel; $\mathbf{g}$, bract; $\mathbf{h}$, flower; i, stamen; j, flower showing the ovary and ovules [M. Silva 868 (MA 751556)]. 


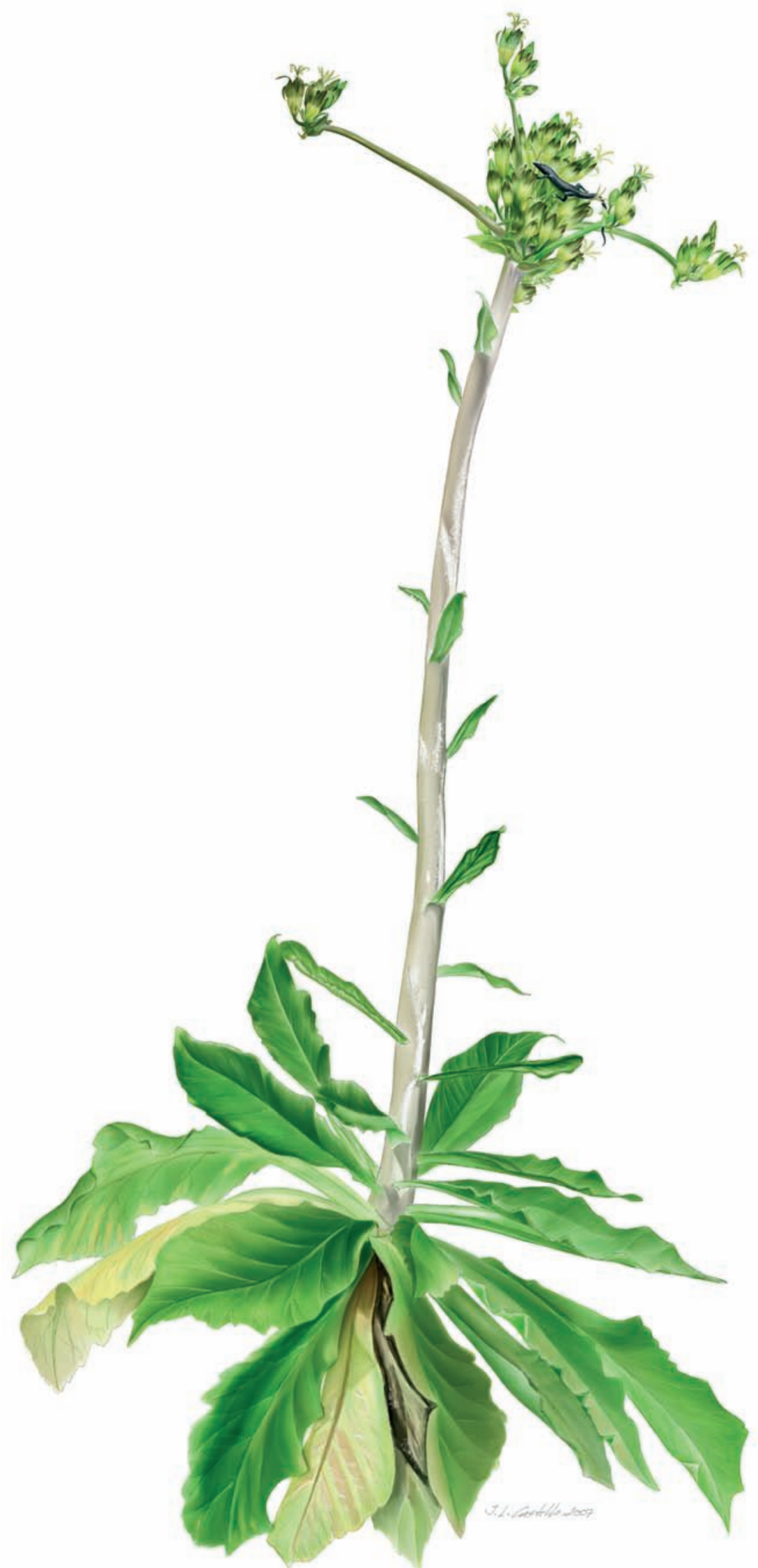

Fig. 3. Musschia isambertoi, colour drawing of the plant habit by Juan Castillo [M. Silva 868 (MA 751556)]. 
Moças, 16-V-2006, M. Silva, L. Carvalho, C. Viveiros E P. Gouveia 868 (MA 751556) (holotype). Portugal, Madeira: Deserta Grande: Rocha basáltica por baixo da casa antiga de vigias das baleias do lado oeste. Local exposto ao sol da tarde e aos ventos de oeste, Vertente oeste da Deserta Grande. 350 m, 10-VI-1992, I. Silva (MADM) (paratype, sub M. wollastonii Lowe).

Etymology. Dedicated and named for its first collector Isamberto Silva, collector of many important plants and arthropods, several of them corresponding to new species to the Madeira archipelago in collaboration with many botanists (and entomologists). Isamberto Silva is also the author of some articles on the flora of Desertas and Selvagens Islands (eg. Costa Neves $\&$ al., 1992; Menezes de Sequeira \& Silva, 2007).

Distribution. Musschia isambertoi is known from only two populations on the Deserta Grande Island, including the population from Fajã Pequena (Fig. 4). Musschia aurea is also present (and is much more common) on this island.

Habitat. Musschia isambertoi seems to grow preferably at almost sea level at damps, the extraordinary habit of this plant immediately strikes the observer, in fact when in flower, it is the largest macro- herb of the Desertas. It does not share a common ecology with Musschia aurea on the Desertas as on Madeira, where M. aurea is a chasmophyte. Several individuals of the Desertas endemic lizard Lacerta dugesii mauli Mertens, 1938, were seen pollinating the flowers of Musschia isambertoi (Fig. 5 b, c). Elvers (1978) refers to lizard pollination in Madeiran plants of Musschia aurea and Olesen \& Valido (2003) further stress the role of lizards as pollinators and seed dispersers on islands, referring to Musschia aurea and Lacerta dugesii Milne-Edwards, 1829. Recently Traveset \& Richardson (2006)) refer to biological invasions as possible disrupters of mutualism and consequences on conservation, this seems to be the case in the Deserta Grande where goats but also rabbits were responsible for massive vegetation destruction. Goat and rabbit eradication was initiated in 1996. Rabbits were totally eradicated and the reduction of goat numbers was followed by a rapid recovery of the flora. The recent increase in goat population seems to be driving most endemics to a population decrease, both in number and in density. On Madeira, the competition by invading plants, such as Opuntia tuna (L.) Mill., may also cause a disruption of mutualism rela-

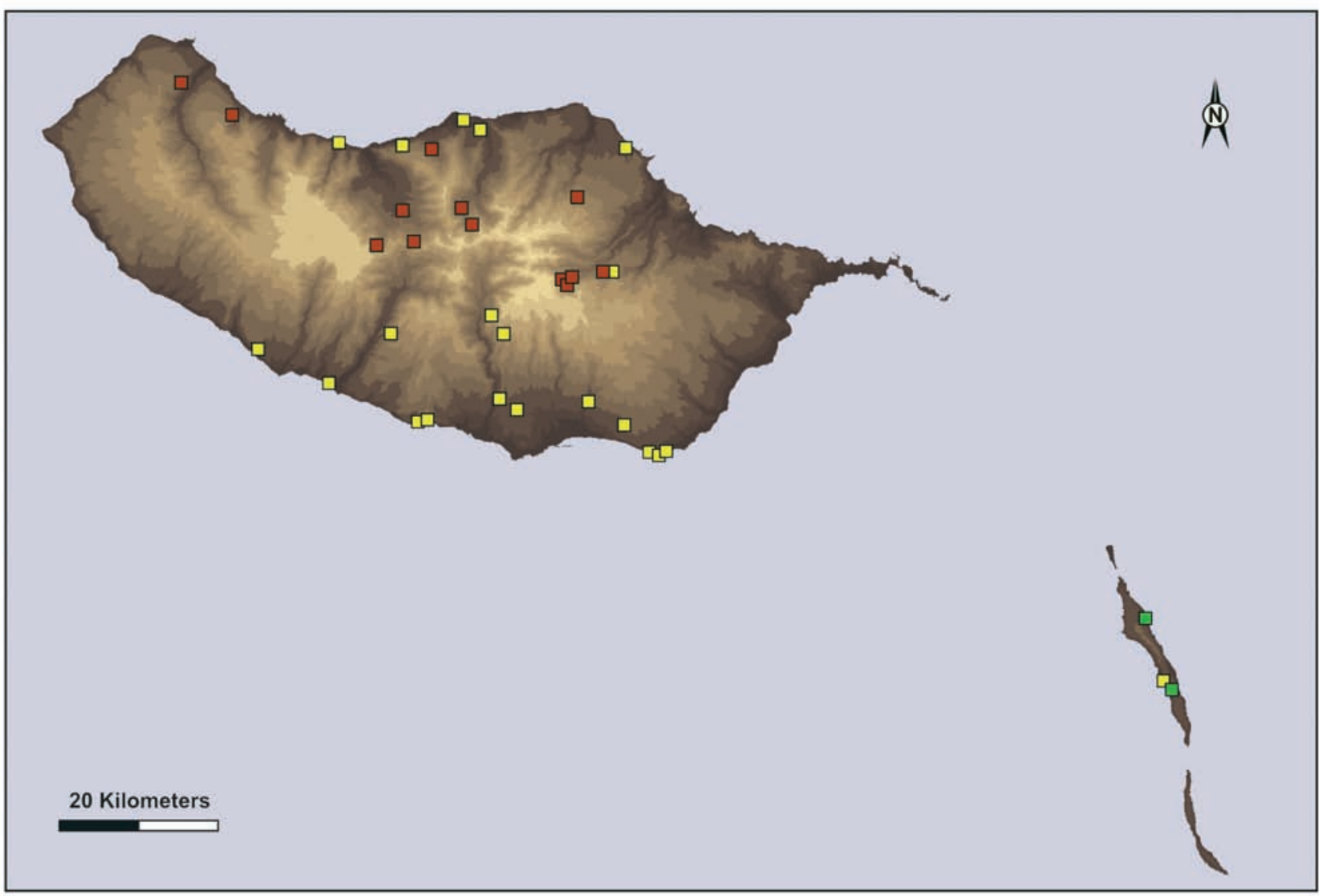

Fig. 4. Distribution of Musschia aurea, yellow squares; M. wollastonii, red squares; M. isambertoi, green squares. 
tions between Lacerta dugesii dugesii and Musschia aurea. Future works on the biological relations between Lacerta dugesii dugesii and Musschia aurea as well as M. isambertoi and the Desertas endemic Lacerta dugesii mauli should enlighten us regarding both mutualism relationships and conservation aspects. Flower colours and inflorescence typical structure are the most important morphological traits that may have evolved from mutualism with reptile pollinators as a co-evolutionary process.

Phenology. Data on flowering is scarce however it seems to flower from May to June.

Conservation status. Due to the scarce number of populations and the reduced occupancy and occurrence area as defined by IUCN (2001), and also due to the grazing effects through the introduction of goats, this new species should be considered as Critically Endangered (CR, C2a(i,ii); D).

Taxonomic remarks. Specimens with the same distinctive morphology had been already collected by Isamberto Silva and included at the local plant collection in Deserta Grande Natural Park facilities, a duplicate of this collection, only a few flowers and a bract, was included at MADM herbarium as Muss- chia wollastonii Lowe, and cited as so in Costa Neves $\&$ al. (1992). Our results strongly suggest a taxonomic differentiation at species level. In fact several morphological characters showed a clear discrepancy with the previously known species. Habit (Figs. 5 a, 6 $\mathrm{a}-\mathrm{c}$ ), leaf shape and hairiness (semi-clasping the stem, oblanceolate, rigid herbaceous, dull, abaxially pubescent and adaxial sparsely scabrid), inflorescence remarkable structure and size (Figs. 5 b, 6), long and unbranched except for the terminal part, with branches disposed at a right angle to the main axis, flower characters (Fig. 7) including: the green to yellowish sepals with their reddish brown apex and veins, larger than those of $M$. aurea and wider than in M. wollastonii; the green corolla with yellowish base, and wide $(4.5-6 \mathrm{~mm})$ lobes; the larger anthers, three times as large as those of $M$. aurea and twice those of M. wollastonii; and the larger stigma, all correspond to diagnostic characters. Table 1 summarizes the diagnostic characters of Musschia isambertoi and compares them with those of $M$. aurea and M. wollastonii. Further studies including chromosome counts and molecular markers may bear light on origin of this new taxon, including a possible hybrid origin that

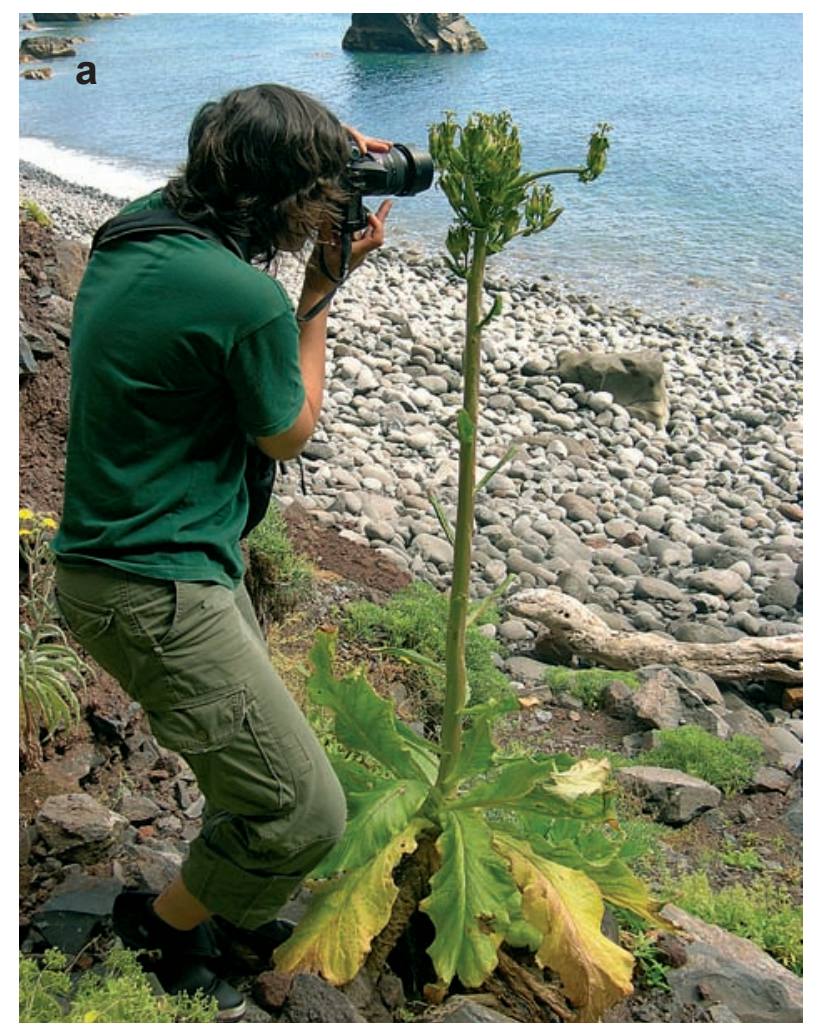

Fig. 5. Habit and inflorescence of Musschia isambertoi: a, habit, one of the authors (L. Carvalho) in Deserta Grande (Porto das Moças); $\mathbf{b}$, aspect of the inflorescence; $\mathbf{c}$, flowers and pollinating lizard, Lacerta dugesii mauli (photographies: M. Silva).
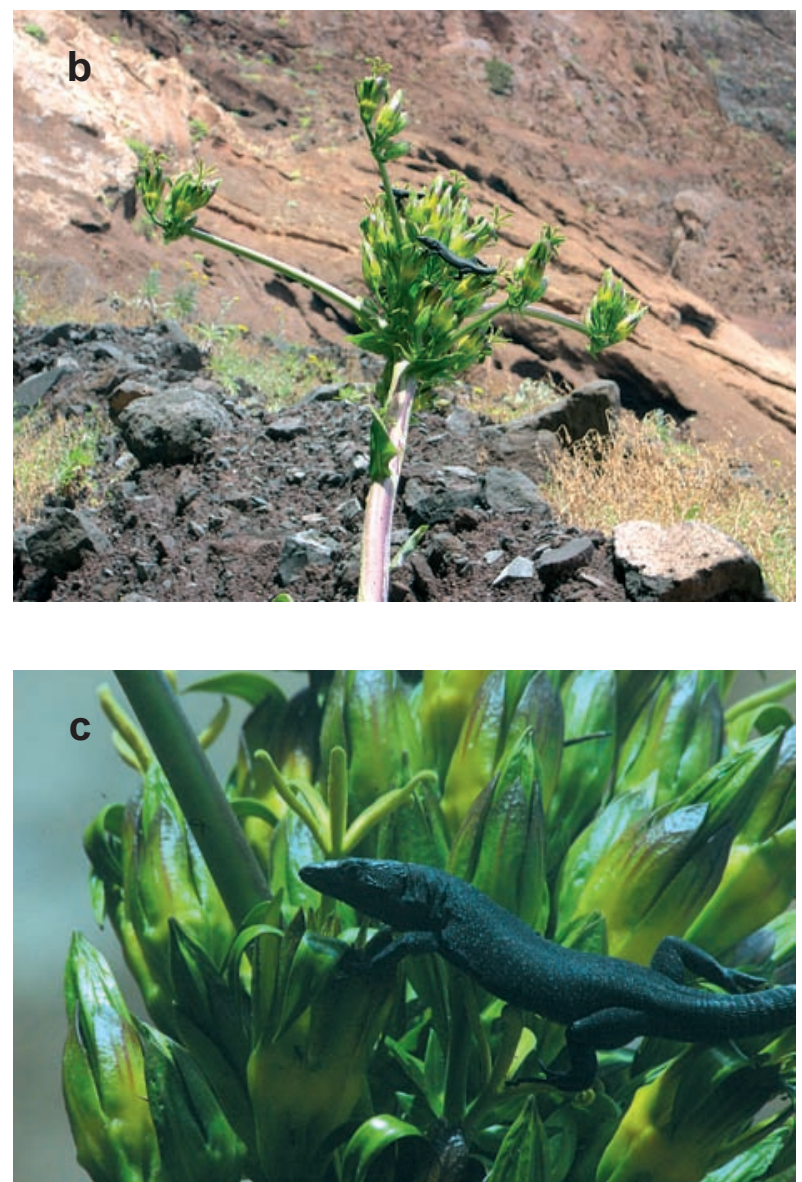
Table 1. Diagnostic characters of Musschia isambertoi versus M. aurea and M. wollastonii.

\begin{tabular}{|c|c|c|c|}
\hline & M. isambertoi & M. aurea & M. wollastonii \\
\hline Indumentum & Glabrous to shortly scabrid & Glabrous & Pubescent \\
\hline Habit & Tall rosetted monocarpic, up to $2 \mathrm{~m}$ & Short not monocarpic, ca. $1 \mathrm{~m}$ & Tall rosetted monocarpic, up to $3 \mathrm{~m}$ \\
\hline Stem & $\begin{array}{l}\text { Stout enlarged, unbranched and } \\
\text { ascending up to } 20-40 \mathrm{~cm}\end{array}$ & $\begin{array}{l}\text { Branched stock supporting several } \\
\text { leaf rosettes, up to } 50 \mathrm{~cm}\end{array}$ & $\begin{array}{l}\text { Robust stout ascending and woody, } \\
\text { up to } 200 \mathrm{~cm}\end{array}$ \\
\hline Leaves & $\begin{array}{l}25-33 \times 11-13 \mathrm{~cm} \text {, semiclasping } \\
\text { the stem, with indistinct petiole, } \\
\text { oblanceolate, rigid herbaceous, } \\
\text { dull, abaxial face glabrous } \\
\text { except for the pubescent veins, } \\
\text { adaxial face sparsely scabrid }\end{array}$ & $\begin{array}{c}10-35 \times 2-5.5 \mathrm{~cm}, \\
\text { not clasping the stem, } \\
\text { ovate to narrow elliptic, } \\
\text { coriaceous, } \\
\text { shiny, } \\
\text { glabrous }\end{array}$ & $\begin{array}{c}14-19 \times 3.5-17 \mathrm{~cm}, \\
\text { clasping the stem, } \\
\text { narrowly oblanceolate, } \\
\text { soft herbaceous, } \\
\text { dull, } \\
\text { with pubescent veins }\end{array}$ \\
\hline Inflorescence & $\begin{array}{l}150 \mathrm{~cm} \text {, branched at the apex, not } \\
\text { pyramidal, flowers densely crowded }\end{array}$ & $\begin{array}{l}40 \mathrm{~cm} \text {, much branched, } \\
\text { pyramidal, flowers not crowded }\end{array}$ & $\begin{array}{l}100 \mathrm{~cm} \text {, much branched, } \\
\text { pyramidal, flowers not crowded }\end{array}$ \\
\hline Sepals & $\begin{array}{l}23-25 \times 5-10 \mathrm{~mm} \text {, green with } \\
\text { reddish brown apex and veins, } \\
\text { sometimes yellowish towards the } \\
\text { base, oblanceolate to oblong, } \\
\text { subapiculate to acuminate }\end{array}$ & $\begin{array}{c}12-18 \times 4-10 \mathrm{~mm} \\
\text { green, } \\
\text { triangular-ovate, } \\
\text { cuspidate }\end{array}$ & $\begin{array}{c}20-25 \times 6 \mathrm{~mm} \\
\text { green to reddish-brown, } \\
\text { narrow triangular-lanceolate, } \\
\text { cuspidate }\end{array}$ \\
\hline Corolla & $\begin{array}{l}\text { Green to olive green, yellowish towards } \\
\text { the base, lobes } 20 \times 4.5-6 \mathrm{~mm}\end{array}$ & $\begin{array}{c}\text { Bright yellow, } \\
\text { lobes } 11-16 \times 3-4 \mathrm{~mm}\end{array}$ & $\begin{array}{c}\text { Reddish brown or sometimes } \\
\text { yellowish, lobes } 21-28 \times 3-5 \mathrm{~mm}\end{array}$ \\
\hline Stamens & $\begin{array}{l}\text { 15-16 mm, shortly apiculate, } \\
\text { pollen yellow }\end{array}$ & $\begin{array}{l}\text { 5-6 mm, shortly apiculate, } \\
\text { pollen yellow }\end{array}$ & $\begin{array}{l}\text { 8-10 mm, apiculate, } \\
\text { pollen white-pinkish }\end{array}$ \\
\hline Stigma & $15-16 \mathrm{~mm}$ & $7-11 \mathrm{~mm}$ & $14-15 \mathrm{~mm}$ \\
\hline
\end{tabular}

could explain some morphological traits (e.g. indumentum and size).

\section{KEY TO MUSSCHIA SPECIES}

1. Plant with leaf rosettes on short stems (less than $50 \mathrm{~cm}$ ); corolla lobes bright yellow or green. .............................. 2 Plant with leaf rosettes on long stems up to 2 meters usually monocarpic; corolla lobes reddish brown or yellowish

2. M. wollastonii

2. Plant monocarpic; leaf rosettes solitary supported by a non branched stem; leaves dull; corolla-lobes green more than 17 $\mathrm{mm}$ long (ca. $20 \mathrm{~mm}$ ); anthers $15 \mathrm{~mm}$.... 3. M. isambertoi Plant not monocarpic; leaf rosettes supported by a usually much branched stock; leaves shiny; corolla-lobes bright yellow less than $17 \mathrm{~mm}$; anthers less than $7 \mathrm{~mm}$. 1. M. aurea

\section{Nomenclature}

1. Musschia aurea (L. f.) Dumort., Comment. Bot.: 28. 1822

Campanula aurea L. f., Suppl. Pl. 141. 1782

Musschia angustifolia Dumort., Comment. Bot.: 29. 1822

Campanula aurea (L. f.) Dumort. var. angustifolia Ker-Gawl. in Bot. Reg. 1: 57. 1815, nom. nudum; Musschia aurea (L. f.) Dumort. var. angustifolia KerGawl. ex DC., Monogr. Campan. 369. 1830

2. Musschia wollastonii Lowe in Hook. Kew Journ. 8: 298.1856
3. Musschia isambertoi M. Seq., R. Jardim, M. Silva \& L. Carvalho

\section{Studied Material}

Musschia aurea (* correspond to the narrow leaved form). PORTUGAL. Madeira: Garajau, 20-VIII-2001, G. Quinn s.n. (MADM 484). Ribeiro Frio, X-1973, C. Pickering 1067485 (MADM 484) (*). Caminho para a Praia do Garajau, VI-2002, J.G. Quinn s.n. (MADM 484). Boaventura, XI (MADS 829) (*). Falésias do Cabo Girão no Poio da Manga abaixo do miradouro, 29-IX-1982, Nóbrega s.n. (MADJ 4044) (*). Deserta Grande, 12IV-1983, Nóbrega \& Rui Santos s.n. (MADJ 6771). Estrada do Curral das Freiras, 25-V-1962, Rui Santos s.n. (MADJ 4042) (*). Estrada do Curral das Freiras, entre túnel do Serrado e o túnel do Córrego dos Açougues, 12-VII-1992 Nóbrega s.n. (MADJ 7786) (sub M. aurea var. longifolia, *). Estrada do Curral das Freiras, entre os dois túneis do Serrado e Córrego de Açougues, 14-VII-1992, Nóbrega s.n. (MADJ 7785) (*). Fajã da Areia, São Vicente, 6-IX1994, Nóbrega s.n. (MADJ 8374) (*). Fajã dos Asnos do fundo do miradouro do Cabo Girão, 20-IV-1992, Nóbrega s.n. (MADJ 7787). Garajau, VII-1921 (MADS 825). Quinta do Bom Sucesso na berma de uma antiga levada, 10-VI-1957, Beliz $\&$ R. Santos s.n. (MADJ 4040). Levada do Norte, entre a Serra de Água e Ribeira Brava, Rocha Alta do Espigão, 17-VI-1982, Nóbrega, Pita \& Rui Santos s.n. (MADJ 4046) (sub M. aurea f. angustifolia, *). Túnel da Ponta Delgada, 1-II-1984, Nóbrega, Pita, Rui Santos E Duarte s.n. (MADJ 4045) (*). Entre a Ponta do Sol e Madalena do Mar, próximo dos Anjos, 6-VI-1957, Beliz E Rui Santos s.n. (MADJ 4039). Praia Formosa, VIII (MADS 826). Estrada da Ribeira Brava, Lugar de Baixo, numa parede, 2-VIII-1957, R. Vieira E R. Santos s.n. (MADJ 4041). Rocha da Escada, falésias marítimas, Santana, 17 XII-1987, Nóbrega s.n. (MADJ 5449) (*). São Martinho, muros de areão ao lado da igreja, 19-VIII-1980, Domingos Noia s.n. (MADJ 

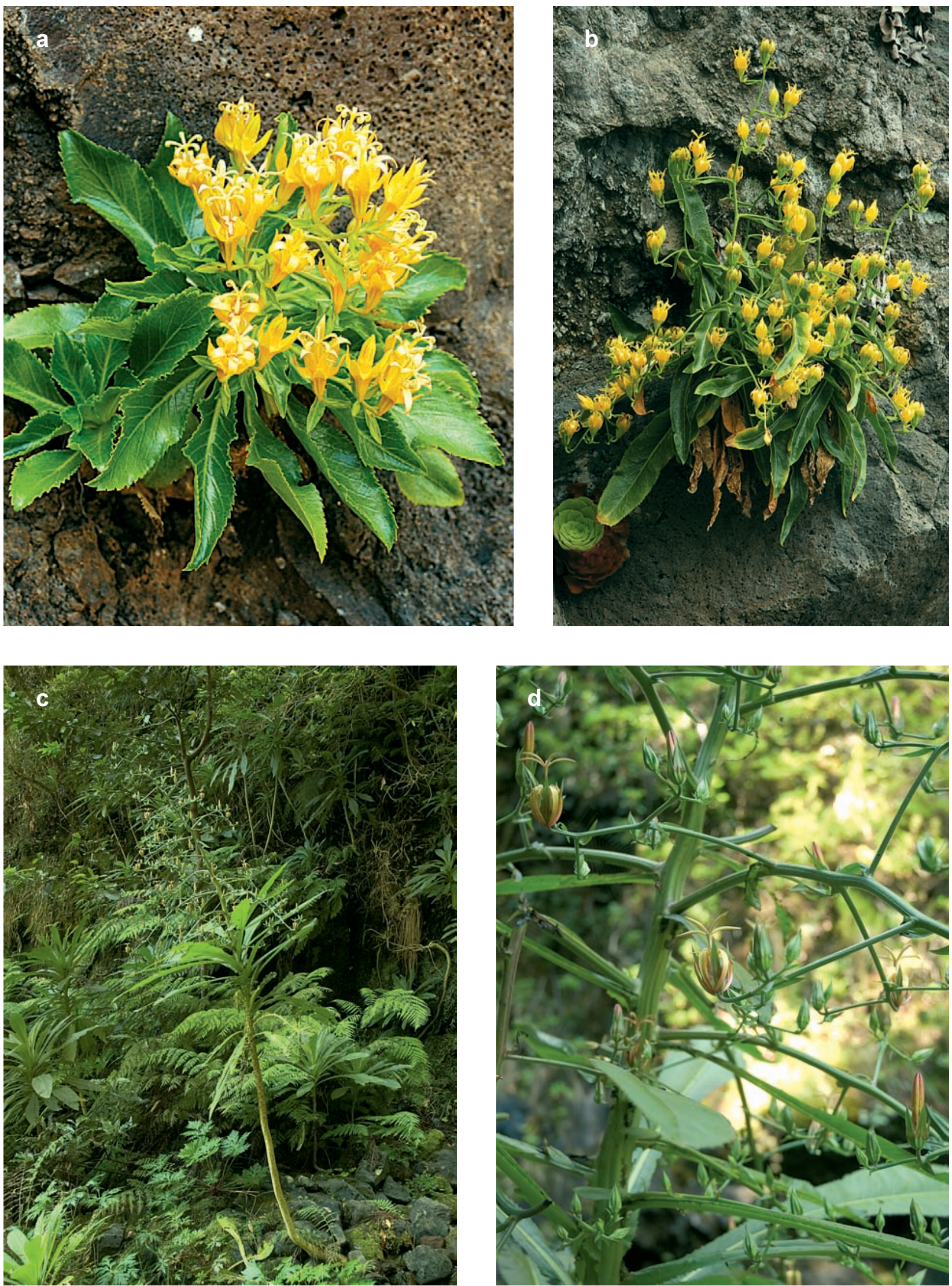

Fig. 6. Habit and inflorescence of Musschia aurea and M. wollastonii: a, M. aurea; b, M. aurea, plant with narrow leaves; c, habit of M. wollastonii; $\mathbf{d}$, inflorescence of M. wollastonii (photographies: M. Menezes de Sequeira). 

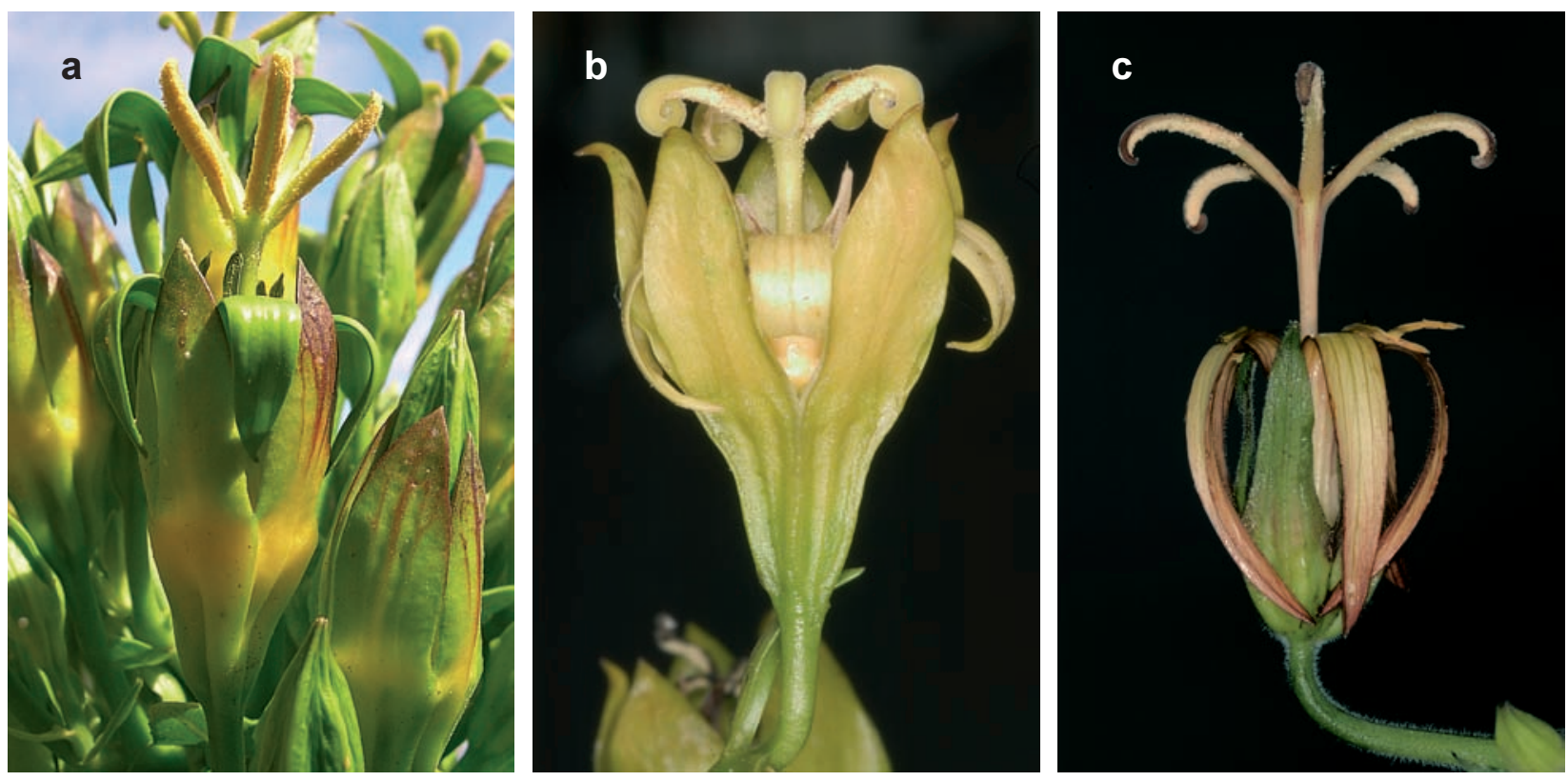

Fig. 7. Detail of a flower, several diagnostic characters are shown, such as sepal colour and veins, green corolla lobes: a, Musschia isambertoi; b, M. aurea; c, M. wollastonii (photographies: a, M. Silva; b, c, M. Menezes de Sequeira).

4043). Volta da Malhada, estrada do Curral das Freiras, vertente da Rib. dos Socorridos, 25-II-1985, Nóbrega, Paulo E Costa s.n. (MADJ 4047) (sub M. aurea f. angustifolia, *). Acima da Praia do Garajau, 14-XII-1989, Nóbrega s.n. (MADJ 2992). São Gonçalo, acima do miradouro, num talude rochoso, 18-V-2005, $255 \mathrm{~m}$, M. Sequeira 4618 (UMad).

Musschia isambertoi. PORTUGAL. Madeira: Ilhas Desertas, Deserta Grande, perto da Fajã Pequena, Porto das Moças, 16-V2006, M. Silva, L. Carvalho, C. Viveiros E P. Gouveia 868 (MA 751556) (holotype). Deserta Grande, rocha basáltica por baixo da casa antiga de vigias das baleias do lado oeste, local exposto ao sol da tarde e aos ventos de oeste, vertente oeste da Deserta Grande, 10-VI-1992, 350 m, Isamberto Silva s.n. (MADM) (paratype, sub M. wollastonii). Deserta Grande Porto das Moças, 22-VI-2001, I.A. Carvalho \& T. Pontes s.n. (MADJ 9586). Deserta Grande, Porto das Moças, 22-VI-2001, J.A. Carvalho E T. Pontes s.n. (MADJ 9587).

Musschia wollastonii. PORTUGAL. Madeira: Rib. Frio, VIII1938, P.T.O. Costa s.n. (MADM 485). Escarpa sobre a Ribeira do Juncal, Córrego do Sabugueiro (S. Roque do Faial), 4-X-1973, C. Andrada s.n. (MADJ 4050). Encumeada, São Vicente, 7-XI-2001, Olga Baeta E P. Gouveia s.n. (MADJ 9689). Levada Central da Rib $^{a}$ da Janela, 28-VI-1984, Nóbrega E Rui Santos s.n. (MADJ 4054). Queimadas, 22-IX-1962, Rui Vieira E Rui Santos s.n. (MADJ 4049). Queimadas, 20-II-1975, Rui Vieira s.n. (MADJ 4057). Rib ${ }^{a}$ da Ponte dos Ganchos, no Urzal de Boaventura, 28VIII-1985, Nóbrega s.n. (MADJ 4055). Rib a do Urzal, Boaventura, junto à levada nova, Caldeirão Verde, 18-I-1984, Nóbrega s.n. (MADJ 4053). Ribeira das Lages, 2-VIII-1962, R. Vieira s.n. (MADJ 4048). Ribeira Funda do Seixal, junto de cascatas que descem do Fanal, 27-VI-1989, Nóbrega s.n. (MADJ 6574). Ribeira Grande, São Vicente, no términos da vereda do Chão dos Louros para a Ribeira Grande, 4-X-1988, Nóbrega s.n. (MADJ 6460). Ribeiro das Feijocas, ao longo da Encumeada de S. Vicente, lev. no km 13, 18-X-1983, Nóbrega, Pita E Isidoro s.n. (MADJ 4052). Parque Florestal do Ribeiro Frio, 5-XI-1982, Nóbrega E Pita (MADJ
4051). Rib ${ }^{\circ}$ do Velho, Ponta Delgada, junto ao "topo de Ponta Delgada”, 3-X-1986, Nóbrega s.n. (MADJ 4056). Ribeira do Juncal, abaixo da levada antiga que dava para o Ribeiro Frio no fundo da Ribeira, 7-VIII-1990, Nóbrega s.n. (MADJ 2818).

\section{Acknowledgements}

We are grateful to the Natural Park of Madeira especially to the director, Susana Fontinha, and to Dília Menezes for collecting premises and the use of the Natural Park of Madeira facilities during field work. We are also grateful to Carlos Viveiros and Pedro Gouveia who guided the field and sea excursions. The authors would also like to acknowledge the help of Sandra Mesquita for the map and Leopoldo Medina for his literature search at the Real Jardín Botánico de Madrid library. The drawings included are due to Juan Castillo and the authors would like to thank him especially. Finally the authors would also like acknowledge to Father M. Laínz for the Latin version of the diagnosis and comments on plant morphology. This article would not be possible without the encouragement of Santiago Castroviejo, his help and reviews were crucial. Finally the authors would like to express their thanks to an anonymous reviewer, her/his critique and suggestions strongly influenced the final output.

\section{References}

Acebes Ginovés, J.R., Del Arco Aguilar, M., García Gallo, A., León Arencibia, M.C., Pérez De Paz, P.L., Rodríguez Delgado, O., Wildpret De La Torre, W., Martín Osorio, V.E., Marrero Gómez, M.C. \& Rodríguez Navarro, M.L. 2004. Pteridophyta \& Spermatophyta. In: Izquierdo, I., Martín, J.L., Zurita, N. \& Arechavaleta, M. (eds.), Lista de especies silvestres de Canarias (hongos, plantas y animales terrestres). Pp. 96-143. Consejería de Medio Ambiente y Ordenación Territorial. Gobierno de Canarias. Aiton, W. 1789. Hortus Kewensis, or a Catalogue of the Plants cultivated in the Royal Botanic Garden at Kew. Vol. 1. Lon- 
don. Printed for George Nicol, Bookseller to his Majesty, Pall Mall

Costa Neves, H., Silva, I. \& Palmeira, C. 1992. Contributions to the knowledge of the flora of Desertas Islands. Bocagiana 163: $1-21$.

Costa, J.C., Capelo, J., Jardim, R. \& Menezes de Sequeira, M. 2004. Catálogo Florístico da Ilha da Madeira. Quercetea 6: 187 200.

De Candolle, A.P.1830. Monographie des Campanulées. Paris. Veuve Desray.

De Candolle, A.P. 1838. Prodromus systematis naturalis regni vegetabilis sive Enumeratio contracta ordinum generum specierum plantarum buc usque cognitarum, juxta methodi naturalis normas digesta. Vol. 7(1). Parisiis. Sumptibus Sociorum Treuttel et Würtz.

Dumortier, B.C. 1823. Commentationes botanicae. Observations botaniques, dédiées à la Société d'Horticulture de Tournay par B.C. Dumortier. Tournay : Imprimerie Ch. Casterman.

Elvers, I. 1978. The Madeiran lizard - flower connection observed in a natural habitat. Botaniska Notiser 131(1): 159-160.

Geldmacher, J., Bogaard, P., Hoernle, K. \& Schmincke, H. 2000. Ar age dating of the Madeira Archipelago and hotspot track (eastern North Atlantic). Geochemistry, Geophysics, Geosystems 1(2) (DOI 10.1029/1999GC000018).

Hansen, A. \& Sunding, P. 1993. Flora of Macaronesia, Checklist of vascular plants, 4. revised edition. Sommerfeltia 17: 1-295.

IUCN. 2001. IUCN Red List categories and Criteria, version 3.1. IUCN Species Survival Commission. IUCN, Gland, Switzerland and Cambridge. United Kingdom.

Jacquin, N. 1804. Plantarum Rariorum Horti Caesarei Schoenbrunnensis Descriptiones et Icones. Vol. 4. Vienna, London.

Jardim, R. \& Francisco, D. 2000. Flora Endémica da Madeira, Múchia Publicações. Funchal.

Ker Gawler, J.B. 1815. Campanula aurea. Botanical Register 1: 57.

Linnaeus f., C. 1782. Supplementum Plantarum Systematis Vegetabilium Editionis Decimae Tertiae, Generum Plantarum Editiones Sextae, et Specierum Plantarum Editionis Secundae. Editum a Carolo a Linné. Brunsvigae.

Lowe, R.T. 1856. Species Plantarum Maderensium quaedam Novae, vel hectenus ineditae, breviter descritae. Hooker's journal of botany and Kew Garden miscellany 8: 289-302.

Lowe, R.T. 1868. A Manual for Flora of Madeira and the adjacent Islands of Porto Santo and the Deserts. Vol. 1(5): 574-577. John Van Voorst. London.

Mabberley, D.J. 1997. The Plant Book. Second Edition. Cambridge University Press. United Kingdom.
Menezes, C.A. 1914. Flora do Arquipélago da Madeira (Phanerogamicas e Cryptogamicas Vasculares). Funchal. Typ. Bazar do Povo.

Menezes de Sequeira \& Silva, I. 2007. Notes on some grasses from the Selvagem Grande (Selvagens archipelago, Portugal). Boletim do Museu Municipal do Funchal (submitted).

Olesen, J.M. \& Valido, A. 2003. Lizards as pollinators and seed dispersers: an island phenomenon. Trends in Ecology and Evolution 18: 177-181.

Press, J.R. \& Short, M.J. 1994. Flora of Madeira. HMSO. London.

Ribeiro, L., Ech-chakroun, S., Mata, J., Boven, A., Mattielli, N., Hus, J \& Maerschalk, C. 2005. Elemental and lead isotopic evidence for coeval heterogeneities at Madeira/Desertas mantle source. In: Anonymous (ed.), Acts of VIII Congresso de Geoquímica dos Países de Lingua Portuguesa (Portugal). Pp. 485488.

Tebbs, B.R. 1994. Campanulaceae. In: Press, J.R. \& Short, M.J. (eds.), Flora of Madeira. Pp. 329-333. HMSO. London.

Turland, N.J. 1994. Musschia Dumort. In: Press, J.R. \& Short, M.J. (eds.), Flora of Madeira. Pp. 331. HMSO. London.

Sánchez-Pinto, L., Leticia Rodríguez, M., Rodríguez, S., Martín, K., Cabrera, A. \& Cármen Marrero, M. 2005. Pteridophyta, Spermatophyta. In: Arechavaleta, M., Zurita, N., Marrero, M.C. \& Martín, J.L. (eds.), Lista preliminary de especies silvestres de Cabio Verde (hongos, plantas y animals terrestres). Pp. 38-57. Consejería de Medio Ambiente y Ordenación Territorial, Gobierno de Canarias.

Silva, L., Pinto, N., Press, B., Rumsay, F., Carine, M., Henderson, S. \& Sjögren, E. 2005. Lista das plantas vasculares (Pteridophyta e Spermatophyta). In: Borges, P.A.V., Cunha, R., Gabriel, R., Martins, A.F., Silva, L. \& Vieira, V. (eds.), A list of the terrestrial fauna (Mollusca and Arthropoda) and flora (Bryophyta, Pteridophyta and Spermatophyta) from the Azores. Pp. 131-156. Direcção Regional do Ambiente and Universidade dos Açores, Horta, Angra do Heroísmo and Ponta Delgada.

Traveset, A. \& Richardson, D.M. 2006. Biological invasions as disruptors of plant reproductive mutualisms. Trends in Ecology and Evolution 21: 208-216.

Ventenat, E.P. 1805. Jardin de la Malmaison. Vol. 2. Paris.

Vieira, R. 1992. Flora da Madeira. O interesse das plantas endémicas macaronésicas. Serviço Nacional de Parques, Reservas e Conservação da Natureza. Lisboa.

Associate Editor: I. Álvarez Received: 10-VIII-2007 Aceppted: $17-\mathrm{X}-2007$ 